Ambiente \& Água - An Interdisciplinary Journal of Applied Science
ISSN 1980-993X - doi:10.4136/1980-993X
www.ambi-agua.net
E-mail: ambi.agua@gmail.com

\title{
Wastewater reuse in irrigation: short-term effect on soil carbon and nitrogen stocks in Brazilian semi-arid region
}

\author{
ARTICLES doi:10.4136/ambi-agua.2623
}

Received: 17 Jul. 2020; Accepted: 03 Nov. 2020

\author{
Marcus Metri Corrêa ${ }^{1^{*} \text {; }}$; Marília Costa Cavalcanti ${ }^{1(D)}$; Dário Costa Primo ${ }^{2}$ (D); \\ Fernando Cartaxo Rolim Neto ${ }^{1}$; ; Jean Manuel Martins ${ }^{3}{ }^{(D}$; \\ Rômulo Simões Cezar Menezes ${ }^{2}$; Antonio Celso Dantas AntoninoiD; \\ Isaque de Souza Mendes ${ }^{4}$; Lívia Regina dos Santos Medeiros ${ }^{5}$ iD \\ ${ }^{1}$ Departamento de Tecnologia Rural. Universidade Federal Rural de Pernambuco (UFRPE), \\ Rua Dom Manoel de Medeiros, s/n, CEP: 52171-900, Recife, PE, Brazil. \\ E-mail: marilia.costac@gmail.com, fernandocartaxo@yahoo.com.br \\ ${ }^{2}$ Departamento de Energia Nuclear. Universidade Federal de Pernambuco (UFPE), Avenida Professor \\ Luís Freire, n ${ }^{\circ}$ 1000, CEP: 50740-540, Recife, PE, Brazil. \\ E-mail: darioprimo@gmail.com,rmenezes@ufpe.br, antonio.antonino@ufpe.br \\ ${ }^{3}$ Institute Geosciences \& Environment - IGE UMR 5001. University Grenoble Alpes, CNRS, IRD, INP-G. 70, \\ Rue de la Piscine, 38000, Grenoble, France. E-mail: jean.martins@ univ-grenoble-alpes.fr \\ ${ }^{4}$ Programa de Pós-Graduação em Engenharia Agrícola (PGEAGRI). Universidade Estadual do Oeste \\ do Paraná (UNIOESTE), Rua Universitária, n 1619, CEP: 85819-110, Cascavel, PR, Brazil. \\ E-mail: isaque.souzamendes11@gmail.com \\ ${ }^{5}$ Secretaria Executiva de Meio Ambiente. Prefeitura Municipal do Cabo de Santo Agostinho,

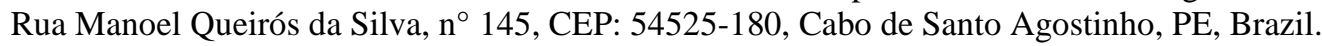 \\ E-mail: dimedeiros.livia@gmail.com \\ *Corresponding author. E-mail: marcus.metri@gmail.com
}

\begin{abstract}
The main process that opposes the Greenhouse Effect is called "carbon sequestration", a phenomenon that essentially seeks to establish a dynamic balance between greenhouse gas (GHG) emissions from the immobilization of its elements, especially $\mathrm{C}$ and $\mathrm{N}$. This work evaluated the stocks of carbon and nitrogen in soils of the Brazilian semi-arid submitted to irrigation with treated wastewater from domestic sewage. For this purpose, the carbon and nitrogen stocks in the soil of the semi-arid region of Brazil were compared for four different uses: Open Native Caatinga (ONC); Treated Wastewater Effluent Irrigation (TSEI); Surface Water Irrigation (SWI); and Traditional Rainfed Agriculture (TRA). The hypothesis considered in this research was that the application of treated effluents in agriculture, besides being an alternative that can mitigate the problem of water scarcity of the semiarid region, is also capable of influencing the storage capacity of $\mathrm{C}$ and $\mathrm{N}$ in the soil, due to its organic load. The results indicate that among the different land uses evaluated, soil $\mathrm{C}$ and $\mathrm{N}$ stocks were highest in $\mathrm{ONC}$, and decreased with the agricultural land use. The greatest accumulation of $\mathrm{C}$ and $\mathrm{N}$ in Caatinga is due to the presence of forest litter, and the influence of irrigation with treated sewage effluent was not detected in the present study. It can be concluded that the contribution of vegetation residues to the soil surface is the main factor contributing to $\mathrm{C}$ and $\mathrm{N}$ storage.
\end{abstract}

Keywords: carbon and nitrogen sequestration, greenhouse effects, land use change, soils.

This is an Open Access article distributed under the terms of the Creative Commons Attribution License, which permits unrestricted use, distribution, and reproduction in any medium, provided the original work is properly cited. 


\section{Reúso de água residual na irrigação: efeito de curto-prazo sobre os estoques de carbono e nitrogênio do solo no semiárido brasileiro}

\section{RESUMO}

O principal processo natural que se contrapõe ao Efeito Estufa é chamado de sequestro de carbono, um fenômeno que essencialmente busca estabelecer um equilíbrio dinâmico entre a emissão dos gases do efeito estufa (GEE) a partir da imobilização de seus elementos, especialmente do $\mathrm{C}$ e $\mathrm{N}$. O presente trabalho teve como objetivo principal avaliar os estoques de $\mathrm{C}$ e $\mathrm{N}$ em solo da região semiárida do Brasil submetido a irrigação com água residual tratada de esgoto doméstico. Para isso, o estoque de carbono e nitrogênio do solo soram comparados para quatro diferentes usos: caatinga nativa aberta $(\mathrm{ONC})$; irrigação com água residual tratada (TSEI); irrigação com água superficial (SWI); e agricultura de sequeiro (TRA). A hipótese levantada na pesquisa foi de que o reuso de efluentes tratados na agricultura, além de ser uma alternativa que pode mitigar a problemática de escassez hídrica da região semiárida, também é capaz de influenciar a capacidade de estocar C e $\mathrm{N}$ no solo devido a sua carga orgânica. Os resultados indicaram que entre os diferentes usos de solos avaliados, os estoques de $\mathrm{C}$ e $\mathrm{N}$ no solo foi maior na ONC diminuindo com o uso do solo para a agricultura. $\mathrm{O}$ maior acúmulo de $\mathrm{C}$ e $\mathrm{N}$ na caatinga deve-se a presença de serrapilheira, não sendo detectado, no presente estudo, influência da irrigação com efluente de esgoto tratado. Conclui-se que o aporte de resíduos de vegetação na superfície do solo vem a ser o fator de maior contribuição para a estocagem de carbono e nitrogênio nos solos estudados.

Palavras-chave: efeito estufa, sequestro de carbono e nitrogênio, solos, variação do uso da terra.

\section{INTRODUCTION}

Although climate variation is part of the evolution of the planet, human activities significantly potentiate greenhouse gas $(\mathrm{GHG})$ emissions and hence global warming (Zhou et al., 2019). Among the factors that contribute most to $\mathrm{CO}_{2}$ emissions are the combustion of fossil fuels (IPCC, 2013) and the conversion of native vegetation areas to areas for human use (Kopittke et al., 2017). The current challenge is to seek to restore GHG concentrations in the atmosphere, and researchers around the world are turning their attention to two main questions: how to reduce GHG emissions and how to immobilize them.

In recent decades, terrestrial ecosystems have been considered as important as oceans in absorbing and storing $\mathrm{C}$ and $\mathrm{N}$ from the atmosphere, thereby minimizing the problem of the greenhouse effect. The largest $\mathrm{C}$ compartment of terrestrial ecosystems is the soil, where it is estimated that up to $30 \mathrm{~cm}$ deep it is about twice the amount of $\mathrm{C}$ present in the atmosphere as $\mathrm{CO}_{2}$ and up to four times that present in plant biomass (Powlson et al., 2011). Therefore, it is clear that any increase or decrease in soil carbon stock has a significant impact on the atmospheric concentration of $\mathrm{CO}_{2}$ affecting the global climate (Gao et al., 2017). Land use changes can also alter the stock of nitrogen $(\mathrm{N})$ in the soil that is closely linked to the Soil Organic Carbon (SOC) stock (Heyn et al., 2019).

Conversely, good management practices can increase soil organic matter content and contribute positively to soil $\mathrm{C}$ and $\mathrm{N}$ stocks (Wells et al., 2019), in addition to reducing $\mathrm{CO}_{2}$ concentration in the atmosphere and potentially mitigating global climate change (Gao et al., 2017). In Brazil, 77\% of $\mathrm{CO}_{2}$ emissions are due to land-use change and the areas most affected are the Cerrado and Amazon biomes (Lapola et al., 2013). There is some research on the influence of land use changes on soil $\mathrm{C}$ and $\mathrm{N}$ stocks in the semi-arid region of Brazil (Sacramento et al., 2013; Santana et al., 2019; Santos et al., 2019), but there are information gaps that have yet to be filled, particular if the reuse of treated effluents in agriculture is 
considered as a sustainable management practice in agriculture. The National Semi-Arid Institute (INSA) has been recommending irrigation of forage palm (Opuntia stricta) with wastewater to provide food security in the livestock activity in the region (Araújo et al., 2019). The reuse of domestic effluents as an alternative source of water in agriculture has been recommended in many studies as a means of increasing water availability in arid and semi-arid regions and addressing water scarcity (Hamilton et al., 2007; Feinerman and Tsur, 2014; Bedbabis et al., 2015; Martinez et al., 2017) and to lessen the use of mineral fertilizers due to the presence of organic material (Marinho et al., 2013).

Therefore, the use of effluents in agriculture can be not only a solution for water, but also an important ally for the mitigation of $\mathrm{CO}_{2}$ concentration in the atmosphere due to the organic material load present. With proper management, some of the carbon can be retained in the soil profile or used for biomass formation, which characterizes the mechanism of carbon sequestration from the atmosphere to the Earth's crust. However, it is known that in order to develop more systematically sustainable management practices and proposals, it is essential to have information on the impacts (positive or negative) on soils and their stocks of $\mathrm{C}, \mathrm{N}$ and other nutrients, caused by the incorporation of new resources and technologies in anthropogenic activities, such as the treatment and reuse of domestic effluent in agriculture.

Given this scenario, this research is based on the assumption that the adoption of new techniques in agricultural systems, such as the agricultural reuse of wastewater, can influence the capacity of soils to accumulate $\mathrm{C}, \mathrm{N}$ and other nutrients. The objective of this work was to assess the stocks of $\mathrm{C}$ and $\mathrm{N}$ in a Planosol soil, located in the municipality of Santana do Seridó, state of Rio Grande do Norte, semi-arid region of Brazil, under four different uses: Open Native Caatinga (ONC); Treated Sewage Effluent Irrigation (TSEI); Surface Water Irrigation (SWI); and Traditional Rainfed Agriculture (TRA).

\section{MATERIALS AND METHODS}

\subsection{Field Site}

The research was conducted in the municipality of Santana do Seridó, located in the southcentral zone of the state of Rio Grande do Norte $\left(6^{\circ} 45^{\prime} 58^{\prime \prime} \mathrm{S} ; 36^{\circ} 44^{\prime} 0^{\prime \prime} \mathrm{W}\right)$. The municipality covers approximately $188.4 \mathrm{~km}^{2}$ and has a population of 2,680 habitants in 2019 (Figure 1). It is characterized by the Caatinga biome, with a semi-arid climate, classified as Bsh according to Köppen and Geiger, with prolonged droughts, low rainfall, annual average of $559 \mathrm{~mm}$, and low hydric potential.

\subsection{Land Use}

In the experimental area, the soil was classified as Planosol, morphologically described and classified according to WRB (FAO, 2014), and four different land use types were identified: 1) Open Native Caatinga vegetation - ONC $\left(6^{\circ} 45^{\prime} 56.2^{\prime \prime} \mathrm{S} ; 36^{\circ} 43^{\prime} 49.9^{\prime \prime} \mathrm{W}\right)$, identified according to the criteria established by the Brazilian Vegetation Technician's Guide (IBGE, 2012); 2) Treated-Sewage Effluent Irrigation -TSEI (6 $\left.6^{\circ} 45^{\prime} 56.9^{\prime \prime} \mathrm{S} ; 36^{\circ} 43^{\prime} 55.7^{\prime \prime} \mathrm{W}\right)$, agriculture with forage palm (Opuntia stricta) irrigated with treated domestic sewage effluent for animal feed; 3) Surface Water Irrigation - SWI (6 $\left.6^{\circ} 46^{\prime} 01.4^{\prime \prime} \mathrm{S} ; 36^{\circ} 44^{\prime} 00.7^{\prime \prime} \mathrm{W}\right)$, agriculture with conventional sprinkler irrigation of tomatoes (Solanum lycopersicum L.), irrigated with surface water; and 4) Traditional Rainfed Agriculture -TRA (6 $45^{\prime} 56.1^{\prime \prime}$ S; 36 $\left.43^{\prime} 54.7^{\prime \prime} \mathrm{W}\right)$, traditional rainfed agriculture, subsistence crops, mainly maize (Zea mays L.) and beans (Phaseolus vulgaris L.), planted during the rainy season with minimum inputs, as shown in Figure 2.

A survey conducted at the site revealed that soil management in the study areas had been in place for at least four years prior to the date of collection of samples. 

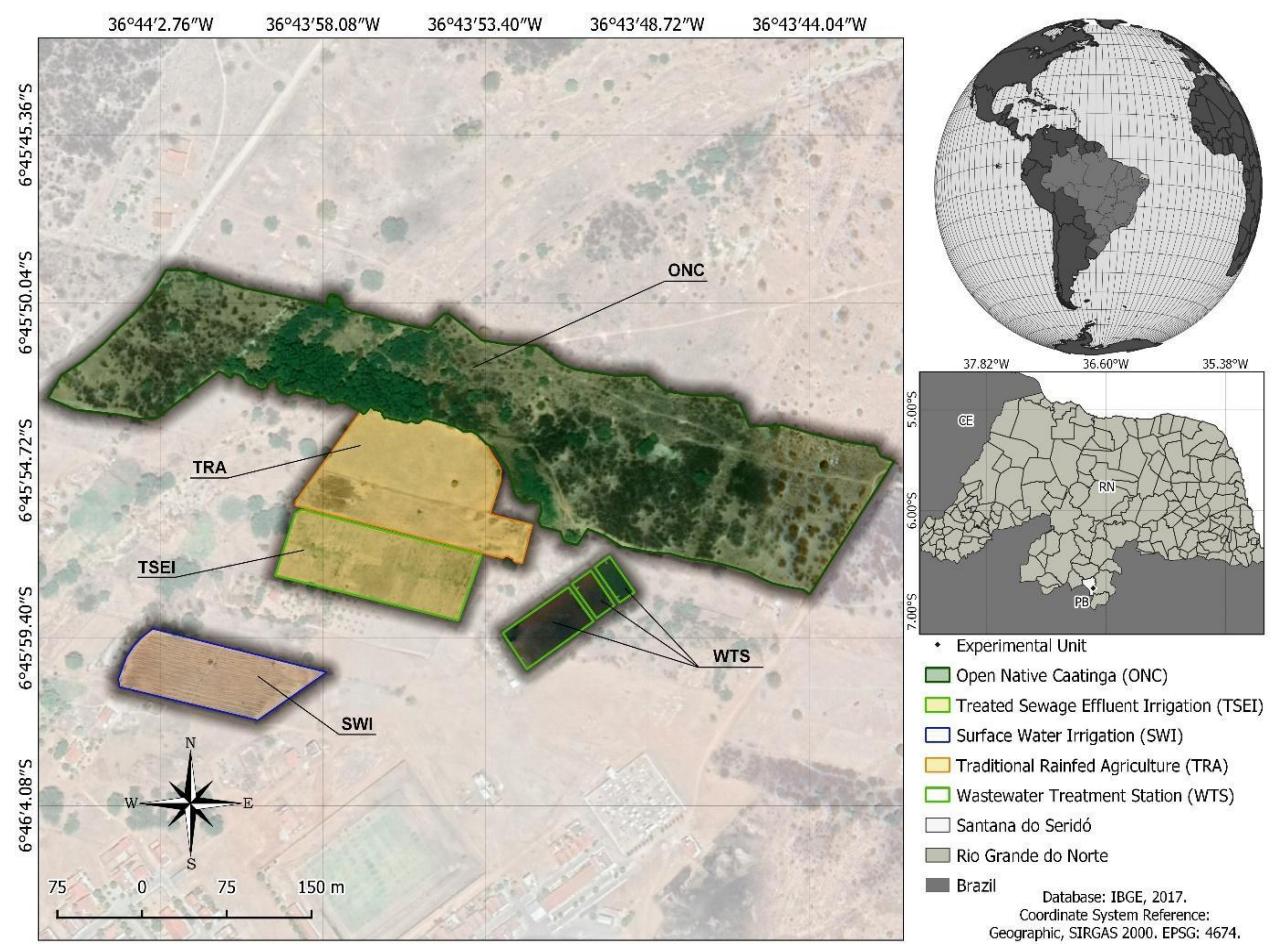

Figure 1. Study area and its location in the state of Rio Grande do Norte, Brazil.
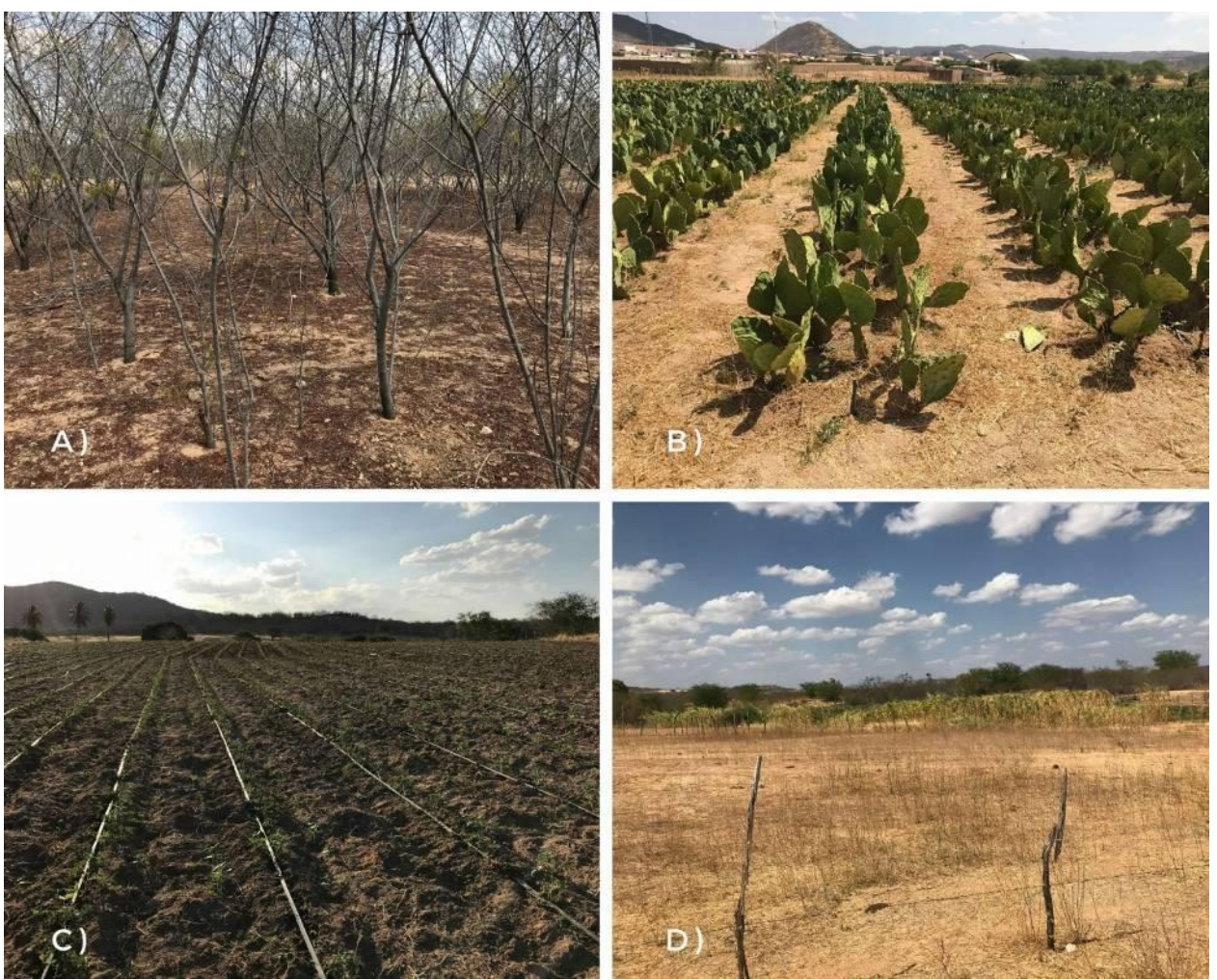

Figure 2. Land uses studied. A) Open Native Caatinga (ONC); B) Treated Sewage Effluent Irrigation (TSEI); C) Surface Water Irrigation (SWI) and D) Traditional Rainfed Agriculture (TRA).

\subsection{Sampling and estimation of soil carbon, nitrogen, calcium, magnesium, potassium and sodium contents}

A total of 32 soil samples were collected for studies on the four land uses, resulting in eight samples per zone. All soil samples collected were packaged in plastic bags, properly labeled 
and sent to the laboratory for processing and analysis. At each site, six soil samples with volumetric rings (core method) were taken to determine soil bulk density, following the methodology of Blake and Hartge (2006).

At the laboratory, the soil samples were air-dried and sieved in $2 \mathrm{~mm}$ mesh size. An aliquot was kept for soil texture characterization, following the methodology presented by Embrapa (2009), and another aliquot was grinded in a ball mill until it passed through a 100 mesh $(0.150$ $\mathrm{mm}$ ). For the quantification of Total Organic Carbon (TOC) levels in the soil, the wet oxidation methodology of Yeomans and Bremner (1988) was used. For the Total Nitrogen (TN) concentration of the soil, the Kjeldahl (Embrapa, 1999) method was used. Stocks were calculated on the basis of $\mathrm{C}$ and $\mathrm{N}$ concentrations and soil volume and density (Veldkamp, 1994) Equation 1:

Stock $=\frac{(\mathrm{T})(\mathrm{Ds})(\mathrm{e})(1-\mathrm{Rv})}{10}$

Where Stock represents the mass of $\mathrm{C}$ or $\mathrm{N}$ per unit area equivalent layer $\left(\mathrm{Mg} \mathrm{ha}^{-1}\right)$; $\mathrm{T}$ is the total $\mathrm{C}$ or $\mathrm{N}$ content in the sampled layer $\left(\mathrm{g} \mathrm{kg}^{-1}\right)$; Ds is the bulk density $\left(\mathrm{kg} \mathrm{dm}^{-3}\right)$; $\mathrm{e}=$ the thickness of the considered layer $(\mathrm{cm})$ and $\mathrm{Rv}$ is the fraction of rock fragments $(>2 \mathrm{~mm})$.

The contents of $\mathrm{Na}$ and $\mathrm{K}$ were extracted with a solution of Mehlich-1 and determined by flame spectrophotometry (Embrapa, 2009) and for $\mathrm{Ca}$ and $\mathrm{Mg}$, the sample extracts obtained with $1 \mathrm{~mol} \mathrm{~L}^{-1} \mathrm{KCl}$ were subjected to atomic absorption (Embrapa, 2009). Phosphorus was determined by colorimetry by reading the intensity of the color of the phosphomolybdic complex produced by the reduction of molybdate with ascorbic acid. The $\mathrm{pH}$ of the samples of soil was determined by direct electrochemical measurement of the effective concentration of $\mathrm{H}^{+}$ions in the soil solution using a combined electrode immersed in a soil/water suspension in a ratio of 1:2.5. To calculate the Sodium Adsorption Ratio (SAR), the concentrations of $\mathrm{Na}, \mathrm{Ca}$ and $\mathrm{Mg}$ determined were used and the following equation was applied Equation 2:

$$
S A R=\frac{N a}{\sqrt{\frac{C a+M g}{2}}}
$$

Where all concentrations were expressed as $\mathrm{mmol} \mathrm{Kg}^{-1}$.

\subsection{Statistical analysis}

The results of the TOC and TN contents and stock variables for all soils were subjected to an analysis of variance (ANOVA) followed by a test of comparison of means (Tukey, 5\%). The statistical program used for the analyzes was Assistant $7.7 \mathrm{pt}$.

\section{RESULTS AND DISCUSSION}

The particle-size distribution of the soil samples collected under the different land uses did not show any significant difference, indicating that they were of the same soil class (Table 1), i.e., sand, thus verifying the predominance of a sand fraction. Sandy soils have a porosity that ensures an important infiltration rate. In addition, soil texture influences its chemical characteristics, such as lower organic matter content and decomposition rate, and low nutrient storage capacity. Sugihara et al. (2012) assessed carbon dynamics in two tropical growing areas in Tanzania with soils of contrasting textures and found that clay soils stored much more carbon than sandy soils. The authors attributed this to the possibility of carbon loss through leaching and macrofauna activity, but this is due to the fact that clays are capable of forming clay-organic complexes, which are less likely to decompose, providing greater physical protection for carbon. Bulk density is considered an attribute that can vary with different management practices. However, as with grain size and despite different land uses, no significant differences 
were identified between bulk density data for the studied areas, including the open native Caatinga area - ONC.

Table 1. Sand, silt and clay contents and density values at two depths in the four studied sites.

\begin{tabular}{|c|c|c|c|c|}
\hline \multirow{2}{*}{ Land Use/Depth } & \multicolumn{3}{|c|}{ Particle Size Distribution (\%) } & \multirow{2}{*}{$\begin{array}{l}\text { Bulk Density } \\
\quad\left(\mathrm{kg} \mathrm{m}^{-3}\right)\end{array}$} \\
\hline & Sand & Silt & Clay & \\
\hline \multicolumn{5}{|c|}{ TSEI } \\
\hline $0-10 \mathrm{~cm}$ & $84.06 \pm 1.14$ & $9.82 \pm 0.77$ & $6.12 \pm 0.83$ & $1.59 \pm 0.03$ \\
\hline $10-20 \mathrm{~cm}$ & $82.85 \pm 1.75$ & $9.60 \pm 1.63$ & $7.56 \pm 1.00$ & $1.69 \pm 0.04$ \\
\hline \multicolumn{5}{|c|}{ SWI } \\
\hline $0-10 \mathrm{~cm}$ & $86.18 \pm 0.83$ & $7.69 \pm 1.06$ & $6.13 \pm 0.45$ & $1.63 \pm 0.04$ \\
\hline $10-20 \mathrm{~cm}$ & $84.85 \pm 1.37$ & $8.10 \pm 1.11$ & $7.05 \pm 2.39$ & $1.67 \pm 0.05$ \\
\hline \multicolumn{5}{|c|}{ TRA } \\
\hline $0-10 \mathrm{~cm}$ & $83.52 \pm 2.63$ & $10.52 \pm 1.55$ & $5.96 \pm 1.18$ & $1.55 \pm 0.04$ \\
\hline $10-20 \mathrm{~cm}$ & $80.17 \pm 1.85$ & $11.60 \pm 1.50$ & $8.24 \pm 1.42$ & $1.62 \pm 0.05$ \\
\hline \multicolumn{5}{|c|}{ ONC } \\
\hline $0-10 \mathrm{~cm}$ & $81.83 \pm 0.44$ & $12.47 \pm 0.99$ & $5.70 \pm 0.61$ & $1.63 \pm 0.06$ \\
\hline $10-20 \mathrm{~cm}$ & $81.05 \pm 0.74$ & $13.63 \pm 1.22$ & $5.32 \pm 0.80$ & $1.65 \pm 0.03$ \\
\hline
\end{tabular}

Mean values obtained from four replicates for Particle-Size Distribution (granulometry) and three replicates for Bulk Density \pm one standard deviation.

Source: Author.

Table 2 shows the total organic carbon (TOC) and total nitrogen (TN) contents for the different land uses. In the $0-10 \mathrm{~cm}$ layer, the native Caatinga vegetation (ONC) had a higher TOC content than the other areas used for agriculture, without significant differences for TN. Similar results were found in the Planosols of the municipality of Jataúba-PE, where concentrations were 8.7 and $8.9 \mathrm{~g} \mathrm{~kg}^{-1} \mathrm{C}$ in conserved areas at depths of $0-14$ and $0-17 \mathrm{~cm}$, while in the degraded environment they were 5.6 and $3.6 \mathrm{~g} \mathrm{~kg}^{-1} \mathrm{C}$ at depths of $0-9$ and $0-20 \mathrm{~cm}$, respectively (Galindo et al., 2008). The presence of higher $\mathrm{C}$ concentrations in open native Caatinga vegetation compared to agriculture areas, confirms the overall behavior that the replacement of forested areas by agriculture areas tends to decrease soil $\mathrm{C}$ and $\mathrm{N}$ concentrations (Wei et al., 2014; Kunlanit et al., 2019). Non-significant differences in N content were also observed by Santana et al. (2019) who attributed this behavior to higher losses of C than $\mathrm{N}$ when land use changes occur. The results obtained here corroborate those of Santana et al. (2019), which resulted in a lower $\mathrm{C} / \mathrm{N}$ ratio of agricultural areas compared to native open Caatinga.

In the Caatinga, TOC levels decrease considerably with increasing depth. This behavior is typical of the situation under native vegetation, because the high input of plant residues on the soil surface favours slow and progressive decomposition, which guarantees the constant incorporation of organic matter into the soil. However, the opposite situation was verified for TN levels, which is probably due to the type of plant residues incorporated (Table 2). As it is a Caatinga-type vegetation, the input of organic waste is poor in $\mathrm{N}$, since, in the semiarid conditions, low soil moisture leads to lower microbial activity near the soil surface, which corroborates the considerations of López-Merino et al. (2015) and Merino et al. (2019). Similarly, the higher $\mathrm{C}$ content in the topsoil may be related to the virtual absence of microbial activity, with the incorporation of the most recalcitrant $\mathrm{C}$ compounds through physical and chemical degradation of the deposited plant residues (Franzluebbers et al., 1996). 
Table 2. Soil C and N contents, Ratio C/N, O.M. content, Soil TOC and TN stocks at two depths in the four studied sites.

\begin{tabular}{|c|c|c|c|c|c|c|}
\hline Land Use & TOC $\left(\mathrm{g} \cdot \mathrm{kg}^{-1}\right)$ & $\mathbf{T N}\left(\mathrm{g} \cdot \mathrm{kg}^{-1}\right)$ & $\begin{array}{c}\mathbf{C : N} \\
\left(\mathrm{g} \cdot \mathrm{kg}^{-1}\right)\end{array}$ & $\begin{array}{c}\text { O.M. (Organic Matter) } \\
\left(\mathrm{g} \cdot \mathrm{kg}^{-1}\right)\end{array}$ & $\begin{array}{c}\text { TOC Stock } \\
\left({\left.\mathrm{Mg} \cdot h a^{-1}\right)}^{2}\right.\end{array}$ & $\begin{array}{l}\text { TN Stock } \\
\left(\text { Mg.ha }^{-1}\right)\end{array}$ \\
\hline \multicolumn{7}{|c|}{$0-10 \mathrm{~cm}$} \\
\hline TSEI & $3.71 \pm 1.11 \mathbf{b}$ & $1.08 \pm 0.26 \mathbf{a}$ & $3.52 \pm 0.83 \mathbf{a}$ & $6.38 \pm 1.90$ & $7.87 \pm 2.34 \mathbf{b}$ & $2.29 \pm 0.55 \mathbf{a}$ \\
\hline SWI & $5.38 \pm 0.69 \mathbf{a b}$ & $1.00 \pm 0.21 \mathbf{a}$ & $5.52 \pm 0.80 \mathbf{a}$ & $9.25 \pm 1.20$ & $11.73 \pm 1.51 \mathbf{a b}$ & $2.18 \pm 0.46 \mathbf{a}$ \\
\hline TRA & $5.45 \pm 1.37 \mathbf{a b}$ & $0.85 \pm 0.11 \mathbf{a}$ & $6.55 \pm 1.91 \mathbf{a}$ & $9.37 \pm 2.35$ & $11.28 \pm 2.83 \mathbf{b}$ & $1.76 \pm 0.23 \mathbf{a}$ \\
\hline ONC & $9.70 \pm 3.07 \mathbf{a}$ & $0.98 \pm 0.63 \mathbf{a}$ & $13.28 \pm 7.95 \mathbf{a}$ & $16.69 \pm 5.29$ & $21.15 \pm 6.70 \mathbf{a}$ & $2.14 \pm 1.38 \mathbf{a}$ \\
\hline \multicolumn{7}{|c|}{$10-20 \mathrm{~cm}$} \\
\hline TSEI & $2.54 \pm 0.90 \mathbf{a}$ & $0.98 \pm 0.22 \mathbf{a}$ & $2.60 \pm 0.76 \mathrm{a}$ & $4.36 \pm 1.54$ & $5.74 \pm 4.06 \mathrm{a}$ & $2.21 \pm 0.98 \mathrm{a}$ \\
\hline SWI & $3.67 \pm 0.25 \mathbf{a}$ & $1.03 \pm 0.23 \mathbf{a}$ & $3.76 \pm 0.84 \mathrm{a}$ & $6.30 \pm 0.42$ & $8.18 \pm 1.09 \mathrm{a}$ & $2.30 \pm 1.02 \mathrm{a}$ \\
\hline TRA & $4.41 \pm 0.64 \mathbf{a}$ & $1.05 \pm 0.18 \mathbf{a}$ & $4.29 \pm 0.77 \mathrm{a}$ & $7.58 \pm 1.10$ & $9.57 \pm 2.78 \mathrm{a}$ & $2.28 \pm 0.78 \mathrm{a}$ \\
\hline ONC & $3.31 \pm 1.05 \mathbf{a}$ & $1.58 \pm 0.65 \mathbf{a}$ & $2.59 \pm 1.36 \mathrm{a}$ & $5.70 \pm 1.81$ & $7.28 \pm 4.63 \mathrm{a}$ & $3.48 \pm 2.86 \mathrm{a}$ \\
\hline
\end{tabular}

Mean values obtained from four replicates \pm one standard deviation. Means followed by the same letter do not differ statistically from each other for the same soil depth.

Source: Author.

Although high, the soil TOC content in Caatinga may correspond to OM that is not incorporated in the mineral fractions of the soil, thus becoming constantly dependent on the input of residues for its maintenance. During the drought period there would be indeed an increase in the content of soil elements, while during the rainy season, with the activity of the soil microbiota, there would be decomposition of these residues and mineralization of $\mathrm{C}$. In this context, low levels of TOC and TN would be justifiable in the agricultural soils studied (Table 2), since in these cultivated areas, especially palm groves, there is little or no replacement of crop residues.

In relation to the additional contributions of organic compounds, caused by the application of irrigation with treated effluents, contrary to what was expected, the total carbon concentrations in the TSE-irrigated soil were significantly lower than those in other areas studied at a depth of $0-10 \mathrm{~cm}$, although this tends to be in balance with the areas of increasing depth (Table 2). A similar result was described by Leuther et al. (2019) in a study conducted in Israel under similar conditions. They found total C and $\mathrm{N}$ concentrations in samples from a soil without irrigation to be significantly higher than in a soil irrigated with treated effluent at a depth of $0-20 \mathrm{~cm}$, with carbon values of 1.74 and $0.83 \mathrm{~g}^{100 \mathrm{~g}^{-1}}$ and

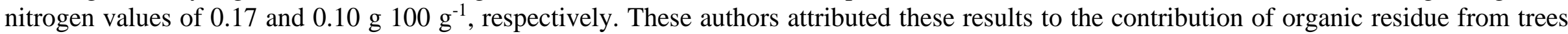
present in the non-irrigated area, without identifying any influence of irrigation water quality on soil carbon $(\mathrm{C})$ and nitrogen $(\mathrm{N})$ concentrations. In the present research, the low quantities of irrigation water applied, due to the fact that the forage palm is a xerophilous plant, combined with the implementation period (4 years) of the reuse project, which can be considered low to promote changes in the organic fraction of the soil, may justify the insignificance of the effect of TSE on soil carbon (C) and nitrogen (N) concentrations. Haynes (2005) suggests that short- to mediumterm crop management is not conducive to significant changes in TOC content. Therefore, in the experimental conditions of the present work, it can be deduced that the contents found would be more reacted to the organomineral complexes of the clay fraction, without irrigation or soil cover interfering with the $\mathrm{C}$ and $\mathrm{N}$ contents. 
The results found for the presence of $\mathrm{C}$ in soils reinforce what Oliveira et al. (2008) verified in their research, showing that the soil surface layers are more sensitive to carbon variations due to the action of microorganisms linked to soil organic matter. Kopittke et al. (2017) argue that $\mathrm{C}$ content tends to decrease in agricultural areas compared to native vegetation, since the conversion of native vegetation to crops reduces the input of plant debris and increases soil temperature, accelerating the decomposition of soil organic matter by microorganisms. Machado (2005) points out that surface C levels tend to decrease, but show little change at greater depths.

The highest $\mathrm{C} / \mathrm{N}$ ratio was observed in Caatinga soils, certainly due to the higher input of plant residues into the soil, while the lowest $\mathrm{C} / \mathrm{N}$ ratio was found in the TSE irrigated soil (Table 2 ). The lower the $\mathrm{C} / \mathrm{N}$ ratio, the greater the decomposition process of organic material. An increase in enzymatic activity has been reported in soils irrigated with treated wastewater (Adrover et al, 2012), suggesting that irrigation with wastewater can stimulate the activity of microorganisms in the biochemical cycle of elements such as $\mathrm{C}, \mathrm{N}$ and $\mathrm{P}$, thus accelerating the mineralization of soil organic matter. This could explain the fact that, in this study, the area irrigated with TSE had the lowest values of $\mathrm{C} / \mathrm{N}$ (more available nitrogen) compared to the other experimental sites. However, in the TSE irrigation site, lower organic matter contents can be found than in the surface water irrigation site. As mentioned above, it is likely that the lower $\mathrm{C} / \mathrm{N}$ ratio favoured rapid mineralization, leading to a decrease in the organic matter content of the soil.

Table 2, which represents TOC and TN stocks in the soils of the different sites studied, indicates that TOC stock in Caatinga exceeds those of the other sites. It was noted that the average TOC and TN stocks for the surface layer of soils are much lower than those verified by Rossato et al. (2007). They found $86 \mathrm{Mg} \mathrm{ha}^{-1}$ and $54 \mathrm{Mg} \mathrm{ha}^{-1}$ of TOC stocks, respectively, in an area of native vegetation and in a corn culture area, sown manually without the use of agricultural input. These authors found also $\mathrm{N}$ stocks of $9 \mathrm{Mg} \mathrm{ha}^{-1}$ and $6 \mathrm{Mg} \mathrm{ha}^{-1}$, respectively, in the same sites. A comparative analysis of the carbon stocks of different Brazilian biomes was carried out by Fidalgo et al. (2007), verifying that the average TOC accumulation for the soils of the Caatinga Biome is $23.7 \mathrm{Mg} \mathrm{ha}^{-1}$. Tiessen et al. (1998) estimated the carbon stock for the soils of this region at $20 \mathrm{Mg} \mathrm{ha}^{-1}$ for the 0-20 cm deep layer, and Fraga and Salcedo (2004) found, in a hyperxerophilic Caatinga, values of $17.9 \mathrm{Mg} \mathrm{ha}^{-1}$ and $28.6 \mathrm{Mg} \mathrm{ha}^{-1}$ for the $0-7.5 \mathrm{~cm}$ and $7.5-15 \mathrm{~cm}$ layers, respectively. These values corroborate the data found in this study for the Caatinga area.

For the other zones studied, the changes resulting from the anthropization process are certainly at the origin of the variation of the soil carbon stock compared to the local native vegetation (Caatinga), with a decrease varying between 44 and $62 \%$. The effect of different cropping systems is highlighted in the study by Giongo et al. (2011), which assessed the carbon stock in preserved Caatinga, altered Caatinga, pastures with Buffel grass and irrigated cropping in a Yellow Argisol, obtaining decreasing values for the TOC stock in the respective order cited, with reductions in the range of 23 to $56 \%$. Giongo et al. (2011) explained these reductions by the assumption that the high temperatures and intensity of sunshine, characteristic of the semiarid climate, associated with high water availability (by irrigation), increase the entropy of the system, resulting in a reduction of the soil carbon stock. In other words, because the rate of mineralization is highly dependent on the soil's water potential, the constant moisture level associated with high temperatures promotes rapid mineralization of organic material added to the soil, a fact also stated by Artiola and Pepper (1992). Thus, effluent irrigation has the potential to modify the recycling processes of $\mathrm{C}$ and $\mathrm{N}$ by increasing soil moisture to levels that stimulate the O.M. decomposition activity of soil microorganisms. These claims may explain the lower values of content and stocks of these nutrients in irrigated areas, especially those irrigated with TSE. It can also be deduced that the deforestation of the native vegetation and of 
soil in rotation for cultivation in the areas studied has led to alteration of the soil structure and intense loss of $\mathrm{C}$ from soil to the atmosphere, considerably reducing the capacity of retention of this element in the soil. Coupled with this, it is likely that little or no input of plant residues in cropping situations will not allow for nutrient recovery and accumulation in the soils studied here.

In Table 3, different from what was observed in the levels of $\mathrm{C}$ and $\mathrm{N}$, it can be seen that the soil irrigated with TSE had higher levels of $\mathrm{Na}$, reaching, at a depth of 10-20 cm, an average value about 10 times higher than that observed in the Caatinga soil, also differing from the treatment with surface water irrigation. Similar results were observed by Barreto et al. (2013) in their study on wastewater irrigation, which increased $\mathrm{Na}^{+}$concentration over the whole profile of soil. Indeed, unlike other cations, $\mathrm{Na}^{+}$has a low affinity for the soil exchange complex found mainly in the soil solution thus facilitating its leachability. Consequently, the $\mathrm{Na}^{+}$added from wastewater moves easily, justifying its higher concentrations with increasing depth (Tarchouna et al., 2010). Barreto et al. (2013) reinforce the above by stating that the rate of water application, the sodium content of the effluent, the absorption capacity of the crop and the soil texture can have a direct influence on the accumulation of this cation along the soil profile.

The high concentration of salts in soil, which may be due to the natural characteristics of the environment itself or to human activities, is capable of affecting the physical and chemical properties of the soil, making it difficult for plants to absorb water. It is noteworthy that high salt concentration in irrigated areas is common, since soluble salts present in irrigation water are added to the soil solution. This is not otherwise the case in the situations studied here, where irrigation water comes from treated sewage and also from a local surface reservoir potentially rich in salts due to the edaphoclimatic characteristics of the semi-arid region.

Salinization probably has the greatest negative impact on irrigated soils in arid and semiarid regions (Diaw et al., 2015), and this risk can be assessed by the soil Sodium Adsorption Ratio (SAR). For the soils in question, analyses indicate a SAR of irrigated soil higher with TSE than with the other waters (Table 3). Medeiros et al. (2005) also found in their studies that a soil that was irrigated had an increased SAR, both when using clean water or wastewater. A similar result was observed by Leuther et al. (2019), who reported that soil sodicity was the most affected factor when comparing non irrigated and irrigated areas with freshwater and treated effluent, with the highest SAR value for plots irrigated with TSE. Although sodicity increased in the soil irrigated with TSE, soils from all treatments can be classified as not affected by salt, with a SAR $<6$ (Rengasamy, 2010). This is due to the fact that the generally very poor sandy clay soils, as in this study, tend to be non-saline and will not have structural problems related to SAR due to their natural high permeability, which facilitates salt leaching during the rainy season. Clay soils, on the other hand, tend to accumulate salts and are rich in sodium, with structural problems that can occur if SAR increases.

For $\mathrm{P}, \mathrm{K}, \mathrm{Ca}$ and $\mathrm{Mg}$ analyses of the soils, in general, the highest results were found in the area irrigated with surface water, followed by the area irrigated with TSE. The excess of soluble salts in soil solution resulting from the accumulation of $\mathrm{Na}^{+}, \mathrm{Ca}^{2+}, \mathrm{Mg}^{2+}$ and $\mathrm{K}^{+}$in the irrigated soil horizons can be due to a combination of several factors, the main ones being soil management (mineral fertilization) and the presence of these elements in wastewater effluents or irrigation water (Qadir and Oster, 2004; Ribeiro, 2010). The average soil phosphorus content differs between treatments, particularly in the area irrigated with water, which presented the highest P content. Kouraa et al. (2002) evaluated the irrigation of potatoes and lettuce with raw sewage, treated wastewater and drinking water, noting that in one cropping year there was no change in the phosphorus content of the cultivated soils. The authors also state that for changes in soil chemical characteristics to take place, several years of irrigation are necessary, since the dynamics of this element are very slow. 
Table 3. Chemical characterization of soil at two soil depths under different uses in Santana do Seridó / RN.

\begin{tabular}{cccccccc}
\hline \multirow{2}{*}{ Land Use/Depths } & \multicolumn{5}{c}{ Elements } \\
\cline { 2 - 7 } & $\begin{array}{c}\mathbf{P} \\
\left(\mathrm{mg} \mathrm{kg}^{-1}\right)\end{array}$ & $\begin{array}{c}\mathbf{K} \\
\left(\mathrm{mg} \mathrm{kg}^{-1}\right)\end{array}$ & $\begin{array}{c}\mathbf{N a} \\
\left(\mathrm{mg} \mathrm{kg}^{-1}\right)\end{array}$ & $\begin{array}{c}\mathbf{C a} \\
\left(\mathrm{mg} \mathrm{kg}^{-1}\right)\end{array}$ & $\begin{array}{c}\mathbf{M g} \\
\left(\mathrm{mg} \mathrm{kg}^{-1}\right)\end{array}$ & $\mathbf{p H}$ & $\mathbf{S A R}$ \\
\hline TSEI & $18.06 \pm 9.55 \mathbf{b}$ & $75.00 \pm 20.27 \mathbf{c}$ & $141.00 \pm 47.88 \mathbf{a}$ & $276.00 \pm 64.30 \mathbf{b}$ & $114.00 \pm 20.98 \mathbf{b}$ & $7.2 \pm 0.65 \mathbf{a}$ & $2.6 \pm 0.94 \mathbf{a}$ \\
SWI & $34.74 \pm 13.13 \mathbf{a}$ & $160.50 \pm 51.68 \mathbf{a}$ & $57.00 \pm 33.80 \mathbf{b}$ & $524.00 \pm 53.73 \mathbf{a}$ & $158.00 \pm 9.10 \mathbf{a}$ & $7.3 \pm 0.34 \mathbf{a}$ & $0.8 \pm 0.48 \mathbf{b}$ \\
TRA & $9.68 \pm 7.46 \mathbf{c}$ & $112.00 \pm 7.35 \mathbf{b}$ & $20.00 \pm 4.56 \mathbf{c}$ & $410.00 \pm 88.59 \mathbf{a}$ & $101.00 \pm 13.88 \mathbf{b}$ & $7.0 \pm 0.08 \mathbf{a}$ & $0.3 \pm 0.09 \mathbf{b}$ \\
ONC & $9.57 \pm 2.98 \mathbf{c}$ & $109.50 \pm 9.10 \mathbf{b}$ & $24.00 \pm 9.38 \mathbf{c}$ & $508.0 \pm 144.53 \mathbf{a}$ & $92.00 \pm 21.07 \mathbf{b}$ & $6.3 \pm 0.07 \mathbf{b}$ & $0.4 \pm 0.10 \mathbf{b}$ \\
\hline & & & $10-20 \mathrm{~cm}$ & & & & \\
\hline TSEI & $13.07 \pm 7.69 \mathbf{b}$ & $80.5 \pm 24.95 \mathbf{c}$ & $215.00 \pm 93.65 \mathbf{a}$ & $274.00 \pm 41.59 \mathbf{b}$ & $119.00 \pm 29.35 \mathbf{b}$ & $7.9 \pm 0.24 \mathbf{a}$ & $3.8 \pm 1.37 \mathbf{a}$ \\
SWI & $28.79 \pm 21.96 \mathbf{a}$ & $140.00 \pm 46.45 \mathbf{a}$ & $82.00 \pm 63.27 \mathbf{b}$ & $500.00 \pm 42.65 \mathbf{a}$ & $154.00 \pm 42.31 \mathbf{a}$ & $7.9 \pm 0.25 \mathbf{a}$ & $1.2 \pm 1.00 \mathbf{b}$ \\
TRA & $5.08 \pm 3.39 \mathbf{c}$ & $121.00 \pm 20.07 \mathbf{b}$ & $23.00 \pm 5.39 \mathbf{c}$ & $379.00 \pm 60.63 \mathbf{b}$ & $113.00 \pm 22.92 \mathbf{b}$ & $7.2 \pm 0.29 \mathbf{b}$ & $0.4 \pm 0.10 \mathbf{b}$ \\
ONC & $4.07 \pm 1.95 \mathbf{c}$ & $113.00 \pm 9.43 \mathbf{b}$ & $22.00 \pm 0.87 \mathbf{c}$ & $357.0 \pm 103.93 \mathbf{b}$ & $94.00 \pm 24.80 \mathbf{c}$ & $6.6 \pm 0.33 \mathbf{c}$ & $0.4 \pm 0.05 \mathbf{b}$ \\
\hline
\end{tabular}

Mean values obtained from four replicates \pm one standard deviation. Means followed by the same letter do not differ statistically from each other for the same soil depth.

Source: Author.

On the other hand, Al-Nakshabandi et al. (1997) contradicted the study mentioned above, because in only five months of growing eggplant irrigated with a treated effluent containing $28 \mathrm{mg} \mathrm{L}^{-1}$ of $\mathrm{PO}_{4}^{-}$, they found a significant increase in soil phosphorus contents. This variation in $\mathrm{P}$ content between studies reinforces what has been said about the influences, not only of the quality of water used for irrigation, but also of irrigation management, vegetation requirements, and the soil and climate characteristics of the region. With regard to the $\mathrm{pH}$ of soils, the values found are close to neutral in all treatments. These results corroborate those obtained by Barreto et al. (2013), who did not observe any change in the pH of soils irrigated with treated effluents. 


\section{CONCLUSIONS}

- Land use had a significant influence on soil carbon and no significant influence on total nitrogen, with native vegetation in Caatinga presenting the highest TOC content compared to the three other areas used for agriculture.

- TOC contents tended to decrease with depth, and the mean TOC and TN stocks for the 0-20 $\mathrm{cm}$ layer were 28.43 $\mathrm{Mg} \mathrm{ha}^{-1}$ and 5.62 $\mathrm{Mg} \mathrm{ha}^{-1}$ for the open Caatinga and 13.61 $\mathrm{Mg} \mathrm{ha}^{-1}$ and $4.50 \mathrm{Mg} \mathrm{ha}^{-1}$ for the TSE irrigation area, respectively.

- The highest $\mathrm{C} / \mathrm{N}$ ratio was found in Caatinga soils, certainly due to the higher natural input of plant residues in the soil, while the lowest $\mathrm{C} / \mathrm{N}$ ratio was observed in the soil irrigated with TSE suggesting that irrigation with wastewater can stimulate the activity of soil microorganisms in the biochemical cycle of elements such as $\mathrm{C}, \mathrm{N}$ and $\mathrm{P}$, thus accelerating the mineralization of soil organic matter.

- The changes in the physicochemical properties of soils due to medium-term irrigation with TSE were mainly observed for significant changes in SAR, reaching, at a depth of 10-20 $\mathrm{cm}$, an average value about 10 times greater than that observed in the Caatinga soil, also differing from the treatment with surface water irrigation.

- The four years of irrigation with TSE in the soil proved to be insufficient to significantly alter the soil TOC and TN stocks in the soil, and under the experimental conditions observed, the treated wastewater reuse technology behaved more like a source of GHGs than a sink.

Finally, it's necessary that long-term research be carried out with the objective of verifying if the reuse of domestic sewage in agriculture (in isolated or combined action) can combat global warming and provide water security needed in semiarid regions.

\section{ACKNOWLEDGMENTS}

The authors of this article would like to thank the CNPq, CAPES and FACEPE for the scholarships awarded to students and researchers as well as for the financial support provided by the following research projects/programs grants: Universal MCTI/CNPq $\mathrm{N}^{\circ}$ 14/2014, MCTI/CNPq No 19/2017 Nexus, MCTI/CNPq/CAPES/FAPS No 16/2014, FACEPE 04/2017, National Observatory of Water and Carbon Dynamics in the Caatinga Biome - NOWCDCB, FACEPE (APQ-0498-3.07/17), CNPq (465764/2014-2), CAPES (88887.136369/2017-00); and CAPES PrInt (88881.318207/2019-01; 88887.371204/2019-00). The authors also thank the Instituto Nacional do Semi Árido (INSA) for providing the structures and materials for the research activities of this study. IGE is part of the Labex OSUG@2020 (ANR10 LABX56).

\section{REFERENCES}

AL-NAKSHABANDI, G. A.; SAQQAR, M. M.; SHATANAWI, M. R.; FAYYAD, M.; ALHORANI, H. Some environmental problems associated with the use of treated wastewater for irrigation in Jordan. Agricultural Water Management, v. 34, p. 81- 94, 1997. https://doi.org/10.1016/S0378-3774(96)01287-5

ADROVER, M.; FARRÚS, E.; MOYÀ, G.; VADELL, J. Chemical properties and biological activity in soils of Mallorca following twenty years of treated wastewater irrigation. Journal of Environmental Management, v. 95, p. S188-S192, 2012. https://doi.org/10.1016/j.jenvman.2010.08.017

ARAÚJO, J. C.; PEREIRA, D. D.; LIRA, E. C.; FÉLIX, E. S.; SOUZA, J. T. A.; LIMA, W. B. Palma forrageira: plantio e manejo. Campina Grande: INSA, 2019. 60p. 
ARTIOLA, J. F.; PEPPER, I. L. Longterm influence of liquid sewage sludge on the organic carbon and nitrogen content of a furrow-irrigated desert soil. Biology and Fertility of Soils, v. 14, p. 30-36, 1992. https://doi.org/10.1007/BF00336299

BARRETO, A. N.; NASCIMENTO, J. J. V. R.; MEDEIROS, E. P.; NÓBREGA, J. A.; BEZERRA, J. R. C. Changes in chemical attributes of a fluvent cultivated with castor bean and irrigated with wastewater. Revista Brasileira de Engenharia Agrícola e Ambiental, v. 17, p. 480-486, 2013. https://doi.org/10.1590/S1415-43662013000500003

BEDBABIS, S.; TRIGUI, D.; BEN AHMED, C.; CLODOVEO, M. L.; CAMPOSEO, S.; VIVALDI, G. A. Long-term effects of irrigation with treated municipal wastewater on soil. yield and olive oil quality. Agricultural Water Management, v. 160, p. 14-21, 2015. https://doi.org/10.1016/j.agwat.2015.06.023

BLAKE, G. R.; HARTGE, K. H. Bulk Density. In: AMERICAN SOCIETY OF AGRONOMY. Methods of Soil Analysis: Part 1-Physical and Mineralogical Methods. SSSA Book Series 5.1. Madison, 2006. p. 377-382.

DIAW, M.; MALL, I.; SANE, S.; MADIOUNE, H. D.; FAYE, S. Assessing of the Suitability for Irrigation Water and Their Repercussions on Land Degradation Process in Delta and Lower Senegal River Valley. American Journal of Water Resources, v. 3, n. 2, p. 32 43, 2015. https://doi.org/10.12691/ajwr-3-2-2

EMBRAPA. Centro Nacional de Pesquisa de Solos. Sistema Brasileiro de Classificação de Solos. Rio de Janeiro, 1999. 412 p.

EMBRAPA. Manual de análises químicas de solos, plantas e fertilizantes. Brasília: Embrapa Solos. Comunicação para Transferência de Tecnologia, 2009. 370p.

FAO. World reference base for soil resources 2014. Roma, 2014. 203 p.

FEINERMAN, E.; TSUR, Y. Perennial crops under stochastic water supply. Agricultural Economics, v. 45, n. 6, p. 757-766, 2014. https://doi.org/10.1111/agec.12120

FIDALGO, E.; BENITES, V.; MACHADO, P.; MADARI, B.; COELHO, M.; MOURA, I.; LIMA, C. Estoque de carbono nos solos do Brasil. Rio de Janeiro: Embrapa Solos, 2007. 27 p.

FRAGA, V. S.; SALCEDO, I. H. Declines of organic nutrient pools in tropical semi-arid soils under subsistence farming. Soil Science Society America Journal, v. 68, p. 215-224, 2004. https://doi.org/10.2136/sssaj2004.2150

FRANZLUEBBERS, A. J.; HANEY, R. L.; HOND, F. M.; ZUBERER, D. A. Determination of microbial biomass and nitrogen mineralization following rewetting of dried soils. Soil Science Society America Journal, v. 60, p. 1133-1139, 1996. https://doi.org/10.2136/sssaj1996.03615995006000040025x

GALINDO, I. C. L.; RIBEIRO, M. R.; SANTOS, M. F. A. V.; LIMA, J. F. W. F.; FERREIRA, R. F. A. L. Relações solo-vegetação em áreas sob processo de desertificação no município de Jataúba-PE. Revista Brasileira de Ciência do Solo, v. 32, p. 1283-1296, 2008. https://doi.org/10.1590/S0100-06832008000300036

GAO, L.; BECKER, E.; LIANG, G.; HOUSSOU, A. A.; WU, H.; WU, X.; CAI, D.; DEGRÉ, A. Effect of different tillage systems on aggregate structure and inner distribution of $\begin{array}{llllll}\text { organic carbon. Geoderma, v. 288, p. 97-104, } 2017 . & \end{array}$ https://doi.org/10.1016/j.geoderma.2016.11.005 
GIONGO, V.; CUNHA, T.; MENDES, A.; GAVA, C. Carbono no sistema solo-planta no Semiárido brasileiro. Revista Brasileira de Geografia Física, v. 4, n. 6, p. 1233-1253, 2011. https://doi.org/10.26848/rbgf.v4i6.232769

HAMILTON, A. J.; STAGNITTI, F.; XIONG, X.; KREIDL, S. L.; BENKE, K. K.; MAHER, P. Waste-water irrigation: the state of play. Vadose Zone Journal, v. 6, p. 823-840, 2007. https://doi.org/10.2136/vzj2007.0026

HAYNES, R. J. Labile organic matter fractions as central components of the quality of agricultural soils: an overview. Advances in Agronomy, v. 85, p. 221-268, 2005. https://doi.org/10.1016/S0065-2113(04)85005-3

HEYN, N.; JOERGENSEN, R. G.; WACHENDORF, C. Soil organic C and N stocks in the first rotation of poplar plantations in Germany. Geoderma Regional, v. 15, n. e00211, 2019. https://doi.org/10.1016/j.geodrs.2019.e00211

IBGE. Indicadores de desenvolvimento sustentável: estudos e pesquisas. Rio de Janeiro, 2012. 350p.

IPCC. Summary for Policymakers. In: IPCC. Climate Change 2013: The Physical Science Basis. Cambridge: Cambridge Univ. Press, 2013. p. 3-29.

KOPITTKE, P. M.; DALAL, R. C.; FINN, D.; MENZIES, N. W. Global changes in soil stocks of carbon, nitrogen, phosphorus, and sulphur as influenced by long-term agricultural production. Global Change Biology, v. 23, p. 2509-2519, 2017. https://doi.org/10.1111/gcb.13513

KOURAA, A.; FETHI, F.; LAHLOU, A.; OUAZZANII, N. Reuse of urban wastewater by combined stabilization pond system in Benslimane (Morocco). Urban Water, v. 4, p. 373-378, 2002. https://doi.org/10.1016/S1462-0758(01)00067-X

KUNLANIT, B.; BUTNAN, S.; VITYAKON, P. Land-Use Changes Influencing C Sequestration and Quality in Topsoil and Subsoil. Agronomy, v. 9, n. 520, p. 1-16, 2019. https://doi.org/10.3390/agronomy9090520

LAPOLA, D. M.; MARTINELLI, L. A.; PERES, C. A.; OMETTO, J. P. H. B.; FERREIRA, M. E.; NOBRE, C. A.; AGUIAR, A. P. D.; BUSTAMANTE, M. M. C.; CARDOSO, M. F.; COSTA, M. H.; JOLY, C. A.; LEITE, C. C.; MOUTINHO, P.; SAMPAIO, G.; STRASSBURG, B. B. N.; VIEIRA, I. C. G. Pervasive transition of the Brazilian landuse system. Nature Climate Change, v. 4, p. 27-35, 2013. https://doi.org/10.1038/nclimate2056

LEUTHER, F.; SCHLUTER, S.; WALLACH, R.; VOGEL, H. Structure and hydraulic properties in soils under long-term irrigation with treated wastewater. Geoderma, v. 333, p. 90-98, 2019. https://doi.org/10.1016/j.geoderma.2018.07.015

LÓPEZ-MERINO, L.; SERRANO, O.; ADAME, M. F.; MATEO, M. Á.; CORTIZAS, A. M. Glomalin accumulated in seagrass sediments reveals past alterations in soil quality due to land-use change. Global and Planetary Change, v. 133, p. 87-95, 2015. https://doi.org/10.1016/j.gloplacha.2015.08.004

MACHADO, P. L. A. Carbono do solo e a mitigação da mudança climática global. Química Nova, v. 28, p. 329-334, 2005. https://doi.org/10.1590/S0100-40422005000200026 
MARINHO, L. E. O.; TONETTI, A. L.; STEFANUTTI, R.; CORAUCCI FILHO, B. Application of reclaimed wastewater in the irrigation of rosebushes. Water Air Soil Pollution, v. 224, n. 1669, p. 1-7, 2013. https://doi.org/10.1007/s11270-013-1669-z

MARTINEZ, P. A.; MARTINEZ, N. G.; MEDINA, J. Q.; ALMELA, L. Domestic wastewaters reuse reclaimed by an improved horizontal subsurface-flow constructed wetland: A case study in the southeast of Spain. Bioresource Technology, v. 233, p. 236-246, 2017. https://doi.org/10.1016/j.biortech.2017.02.123

MEDEIROS, S. S.; SOARES, A. A.; FERREIRA, P. A.; NEVES, J. C. L.; MATOS, A. T.; SOUZA, J. A. A. Utilização de água residuária de origem doméstica na agricultura: Estudo das alterações químicas do solo. Revista Brasileira de Engenharia Agrícola e Ambiental, v. 9, n. 4, p. 603-612, 2005. https://doi.org/10.1590/S141543662005000400026

MERINO, A.; JIMÉNEZ, E.; FERNÁNDEZ, C.; FONTÚRBEL, M. T.; CAMPO, J.; VEGA, J. A. Soil organic matter and phosphorus dynamics after low intensity prescribed burning in forests and shrubland. Journal of Environmental Management, v. 234, p. 214-225, 2019. https://doi.org/10.1016/j.jenvman.2018.12.055

OLIVEIRA, J. T.; SANTOS, A. M. S.; MOREAU, A. M.; MENEZES, A. A.; COSTA, O. V. Características físicas e carbono orgânico de solos sob diferentes tipos de uso da terra. Revista Brasileira de Ciência do Solo, v. 32, p. 2821-2829, 2008. https://doi.org/10.1590/S0100-06832008000700028

POWLSON, D. S.; GREGORY, P. J.; WHALLEY, W. L.; QUINTON, J. N.; HOPKINS, D. W.; WHITMORE, A. P.; HIRSCH, P. R.; GOULDING, K. W. T. Soil management in relation to sustainable agriculture and ecosystem services. Food Policy, v. 36, p. S72S87, 2011. https://doi.org/10.1016/j.foodpol.2010.11.025

QADIR, M.; OSTER, J. D. Crop and irrigation management strategies for saline-sodic soils and waters aime at environmentally sustainable agriculture. Science of The Total $\begin{array}{lllllll}\text { Environment, } & \text { v. } 323, \quad \text { n. } & 1-3, & \text { p. } & 1-19,\end{array}$ https://doi.org/10.1016/j.scitotenv.2003.10.012

RENGASAMY, P. Soil processes affecting crop production in salt-affected soils. Functional Plant Biology, v. 37, n. 7, p. 613-620, 2010. https://doi.org/10.1071/FP09249

RIBEIRO, M. R. Origem e Classificação dos Solos Afetados por Sais. In: GHEYI, H. R.; DIAS, N. S.; LACERDA, C. F. (Eds.). Manejo da Salinidade na Agricultura: Estudos Básicos e Aplicados. Fortaleza: INCTSal, 2010. p.11-19

ROSSATO, M.; BARBIERI, R. L.; SCHÄFER, A.; ZACARIA, J. Caracterização molecular de populações de palmeiras do gênero Butia do Rio Grande do Sul através de marcadores ISSR. Magistra, v. 19, n. 4, p. 311-318, 2007.

SACRAMENTO, J. A. A. S.; ARAÚJO, A. C. de M.; ESCOBAR, M. E. O.; XAVIER, F. A. da S.; CAVALCANTE, A. C. R.; OLIVEIRA, T. S. Soil carbon and nitrogen stocks in traditional agricultural and agroforestry systems in the semiarid region of Brazil. Revista Brasileira Ciência do Solo, v. 37, p. 784-795, 2013. https://doi.org/10.1590/S010006832013000300025 
SANTANA, M. S.; SAMPAIO, E. V. S. B.; GIONGO, V.; MENEZES, R. S. C.; JESUS, K. N.; ALBUQUERQUE, E. R. G. M.; NASCIMENTO, D. M.; PARENY, F. G. C.; CUNHA, T. J. F.; SAMPAIO, R. M. B.; PRIMO, D. C. Carbon and nitrogen stocks of soils under different land uses in Pernambuco state, Brazil. Geoderma Regional, v. 15, n. e00205, 2019. https://doi.org/10.1016/j.geodrs.2019.e00205

SANTOS, U. J. dos; MEDEIROS, E. V. de; DUDA, G. P.; MARQUES, M. C.; SOUZA, E. S. de; BROSSARD, M. Land use changes the soil carbon stocks, microbial biomass and fatty acid methyl ester (FAME) in Brazilian semiarid área. Archives of Agronomy and Soil Science, v. 65, p. 755-769, 2019. https://doi.org/10.1080/03650340.2018.1523544

SUGIHARA, S.; FUNAKAWA, S.; KILASARA, M.; KOSAKI, T. Effects of land management on $\mathrm{CO}_{2}$ flux and soil $\mathrm{C}$ stock in two Tanzanian croplands with contrasting soil texture. Soil Biology \& Biochemistry, v. 46, p. 1-9, 2012. https://doi.org/10.1016/j.soilbio.2011.10.013

TARCHOUNA, L. G.; MERDY, P.; RAYNAUD, M.; PFEIFER, H. R.; LUCAS, Y. Effects of long-term irrigation with treated wastewater. Part 1: Evolution of soil physico-chemical properties. Applied Geochemistry, v. 25, p. 1703-1710, 2010. https://doi.org/10.1016/j.apgeochem.2010.08.018

TIESSEN, H.; CUEVAS, E.; SALCEDO, I. H. Organic matter stability and nutrient availability under temperate and tropical conditions. Advances in GeoEcology, v. 31, p. 415-422, 1998.

VELDKAMP, E. Organic Carbon Turnover in Three Tropical Soils under Pasture after Deforestation. Soil Science Society of America Journal, v. 58, p. 175-180, 1994. https://doi.org/10.2136/sssaj1994.03615995005800010025x

WEI, X.; SHAO, M.; GALE, W.; LI, L. Global pattern of soil carbon losses due to the conversion of forests to agricultural land. Scientific Reports, v. 4, p. 1-6, 2014. https://doi.org/10.1038/srep04062

WELLS, T.; HANCOCK, G. R.; MARTINEZ, C.; DEVER, C.; KUNKEL, V.; GIBSON, A. Differences in soil organic carbon and soil erosion for native pasture and minimum till agricultural management systems. Science of the Total Environment, v. 666, p. 618630, 2019. https://doi.org/10.1016/j.scitotenv.2019.02.097

YEOMANS, J. C.; BREMNER, J. M. A rapid and precise method for routine determination of organic carbon in soil. Communications in Soil Science and Plant Analysis, v. 19, p. 1467-1476, 1988. https://doi.org/10.1080/00103628809368027

ZHOU, Y.; LIU, W.; LV, X.; CHEN, X.; SHEN, M. Investigating interior driving factors and cross-industrial linkages of carbon emission efficiency in China's construction industry: Based on Super-SBM DEA and GVAR model. Journal of Cleaner Production, v. 241, n. 118322, 2019. https://doi.org/10.1016/j.jclepro.2019.118322 